\title{
Serine/Threonine-Protein Kinase Nek2
}

National Cancer Institute

\section{Source}

National Cancer Institute. Serine/Threonine-Protein Kinase Nek2. NCI Thesaurus. Code C138106.

Serine/threonine-protein kinase Nek2 (445 aa, $\sim 52 \mathrm{kDa}$ ) is encoded by the human NEK2 gene. This protein plays a role in chromosome dynamics during cell division. 